\title{
The Impact of Tower Base Transceiver Station (BTS) Infrastructure Development on the Resident Environment
}

\author{
Fitria Nur Illahi Dinati*, F Rooslan Edy Santosa, Ronny Durrotun Nasihien \\ Department of Civil Engineering, Faculty of Engineering, Narotama University, Indonesia \\ *Corresponding author e-mail: dinatifitria@gmail.com
}

Manuscript received 23 Feb 2021; revised 2 March. 2021; accepted 15 March 2021. Date of publication 2 April 2021

\begin{abstract}
The development of the telecommunications industry in Indonesia is extremely rapid. It can be seen from the telecommunications operator vendors who served as telecommunications specialist co-ops rivaling each other in giving the best service to seize the attention of the Indonesian citizen, which requires telecommunications needs. Numerous realities have developed in various regions stating that the existence of Base Tower Transceiver Station (BTS) has resistance from the residents, which are caused by health issues (radiation), safety issues, to the problem of social value. Moreover, some people from residents supported the construction of Base Tower Transceiver (BTS) since the rental price of land for the tower construction is quite high. This study uses primary data from 100 respondents. The analysis technique uses multiple linear regression analysis, which is processed using SPSS (Statistical Product and Service Solution). The next step is to test the validity, reliability, and examine the classical assumptions (including normality test, autocorrelation test, and heteroscedasticity test). In the end, it can be concluded that the people of Rungkut sub-district in Surabaya, mostly enjoyed the benefits of the construction of the existence of the Telecommunications Tower Infrastructure around them.
\end{abstract}

Keywords: BTS Tower Construction, Telecommunications, Radiation Antenna.

\section{Introduction}

The development of information technology provides a great advantage for countries around the world, both in the utilization of business or use in the needs of human life [1]. The development of information technology has caused significant social changes to take place quickly [2]. The growth of the telecommunications industry in Indonesia is very rapid, marked by the telecommunications operator vendors who served as telecommunications providers rivaling each other in giving the best service to seize the attention of the Indon esian citizen, which requires telecommunications needs [3]. One crucial factor supporting the telecommunications operator vendors is the construction of telecommunication towers (BTS) [4].

Problem

1. What is the level of satisfaction and dissatisfaction of the community in Rungkut District on the construction of the BTS tower infrastructure

2. What is the level of concern for the resident in Rungkut sub-district on the BTS tower infrastructure development.

3. How was the response from the resident and related institutions in Rungkut sub-district about the BTS tower infrastructure development.

Purpose

1. To test the value of the satisfaction and dissatisfaction percentage of the resident in Rungkut sub-district towards the existence of the BTS Tower in infrastructure development.

2. To measure the level of public concern about the construction of Tower Infrastructure in Rungkut sub-district, Surabaya.

3. To analyze the value of the validation test responses from the resident about the construction of telecommunications towers (BTS).

\section{Literature Review}

\subsection{Previous Studies}

The following are several studies related to the evaluation of the effect of the construction of a BTS (Base Transceiver Station) tower:

a. Rofiqoh Ethics Amalin and Dewi Martha Erli Handayeni in 2011, Location Criteria for Construction of BTS Tower (Base Transceiver Station) in Kediri City. In this study, to determine the criteria for the location of BTS tower construction, 
qualitative and quantitative research were used. The data used in this study is qualitative data that has been changed in quantitative form. In this study, data collection was done through primary surveys. The data was obtained using interviews and questionnaires to all participants involved in the construction of the BTS tower [5].

b. (Ngatono, March 2016). The Influence of Telecommunication Infrastructure on Economic Growth in Banten Province in 2004-2013. This study analyzed how significant is the impact of telecommunications infrastructure represented by the number of BTS (Base Transceiver Station) on the economic value of growth represented by GDP (Gross Domestic Product). This study uses the Least Square Regression method, which gives the results of the value of the number of telecommunications infrastructure affecting economic growth in Banten [6].

c. Sunaryati in 2010, Analysis of the Impact of Cell Phones (Base Transceiver Station) on Increased Environmental Radiation. Due to the issue of radiation produced by BTS that can disrupt the health of the surrounding community, this study was conducted to reveal the pattern of the intensity distribution of electromagnetic field radiation around cell phone BTS [7].

\subsection{Infrastructure}

a. Telecommunications Infrastructure

The availability of telecommunications infrastructure has a role in generating economic opportunities for the community to develop business, education, tourism, entertainment, the creative economy industry. Through the construction of telecommunications infrastructure that is be spread evenly in each region can improve the quality of information for the people. It can be a tool for various activities to be more productive [4] [3].

b. Tower BTS

The Base Transceiver Station (BTS) component is a capable device of receiving and transmitting signals properly. One of the elements from the BTS is the Telecommunications Tower, which is used to call the BTS Tower. The tower was made from iron and pipes arranged together in rectangular or triangle. The function of the tower is to place the antenna and radio transmitter or telecommunications and information of the receiver. Tower BTS (Base Transceiver Station) as a tool of communication and information [8].

Impact of Tower BTS Infrastructure Development on the resident environment [9].

a. Numerous facts have appeared in the regions stating that the existence of telecommunication towers or BTS towers has pros and cons responses to people's safety. There is also a good response to the BTS tower due to advances in technology are developing rapidly.

b. Cultural change to modernization by utilizing the progress of science and technology will make daily human activities more effective and efficient.

c. There is improved access to the location area around the tower, for instance, the installation of street lighting.

d. The existence of BTS Tower can raise the economy level of residents by leasing land.

e. The tower construction activity can create new jobs.

The negative response to the construction of the BTS tower is because:

a. The resident has risks of being crushed by nearby towers.

b. The resident can have health problems because of the radiation issue.

c. Damage to electronic equipment due to lightning-prone strikes.

d. The land around the BTS tower is hard to contract or sell.

e. The mushrooming of the tower can affect an unsightly city layout.

The government suffers a loss due to mushrooming towers that were established with or without permission. 


\section{Method}

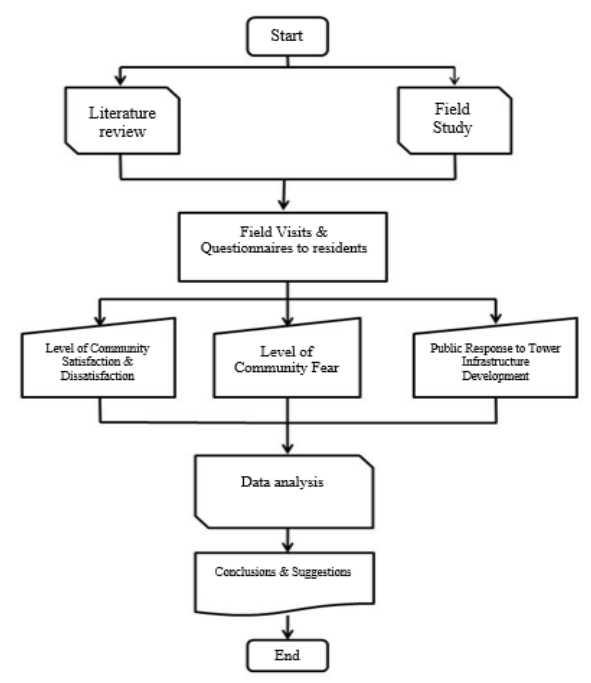

Fig 1. Research Flow Chart

\section{Results and Discussion}

\subsection{Type of Respondents}

The respondents grouped into two groups based on sex, male and female, which show in the following table and graph.

Table 1. Gender of Respondents

\begin{tabular}{llrrrr}
\hline & & Frequency & Percent & Valid Percent & Cumulative Percent \\
\cline { 3 - 6 } Valid & Female & 58 & 58.0 & 58.0 & 58.0 \\
& Male & 42 & 42.0 & 42.0 & 100.0 \\
& Total & 100 & 100.0 & 100.0 & \\
\hline
\end{tabular}

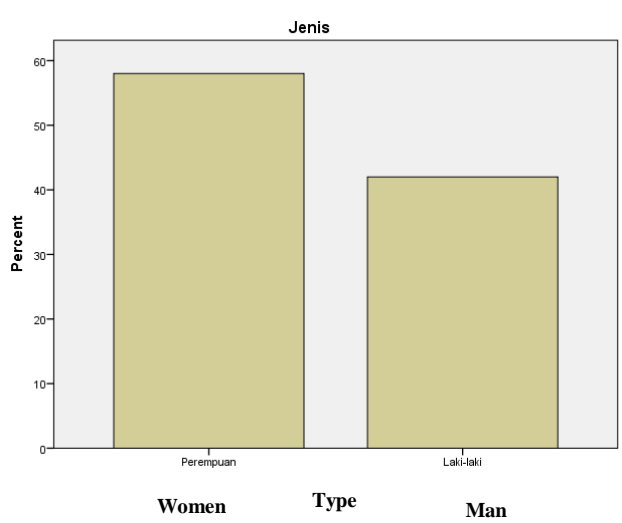

Fig 2. Graphic Gender of the respondent

Based on the table and graph above, it can be seen that most respondents are female respondents, as much as 58 people or $58 \%$, while respondents with male sex are 48 people or $48 \%$.

\subsection{Age}

Respondents can be classified into five groups based on their age, which are age less than 17 years, age 17-25 years, age 26-45 years, age 46-65 years, and age over 65 years, which shows in the following tables and graphs.

Table 2. Age of Respondents

\begin{tabular}{rlrrrr}
\hline & Frequency & Percent & Valid Percent & Cumulative Percent \\
\hline \multirow{4}{*}{ Valid } & $17-25$ & 27 & 27.0 & 27.0 & 27.0 \\
& $<17$ & 23 & 23.0 & 23.0 & 50.0 \\
& $26-45$ & 21 & 21.0 & 21.0 & 71.0 \\
& $45-65$ & 19 & 19.0 & 19.0 & 90.0 \\
& $>65$ & 10 & 10.0 & 10.0 & 100.0 \\
& Total & 100 & 100.0 & 100.0 & \\
\hline
\end{tabular}




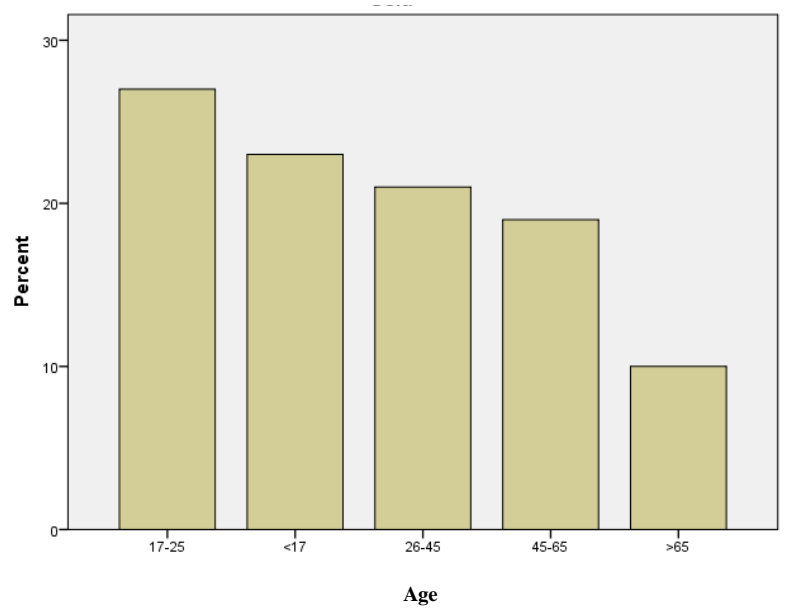

Fig 2. Age Graph of Respondents

Based on the age of the respondent's table and graph above, most respondents are the age of 17-25 years old as many as 27 respondents (27\%). For respondents, under 17 years old, that is as many as 23 people (23\%). Next is respondents at 26-45 years old as many as 21 people or $(21 \%)$. For respondents with ages $45-65$ years old as many as 19 people (19\%). The least are respondents with age over 65 years old there are ten people or $10 \%$.

\subsection{Profession}

Respondents based on their work can be grouped into five groups, which are students, civil servants, private-sector workers, entrepreneurs, and others that can found in the following table and graph.

Table 3. Respondents' Work

\begin{tabular}{llrrrr}
\hline & Frequency & Percent & Valid Percent & Cumulative Percent \\
\cline { 3 - 6 } & Student / Student & 42 & 42.0 & 42.0 & 42.0 \\
& Private-Sector Workers & 18 & 18.0 & 18.0 & 60.0 \\
Valid & 16 & 16.0 & 16.0 & 76.0 \\
& Entrepreneur & 15 & 15.0 & 15.0 & 91.0 \\
& Civil servants & 9 & 9.0 & 9.0 & 100.0 \\
& Others & 100 & 100.0 & 100.0 & \\
Total & & &
\end{tabular}

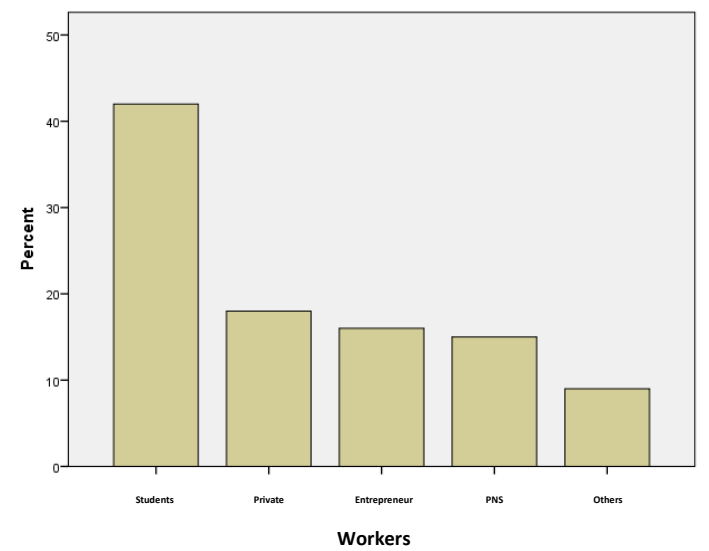

Fig 3. Graph of Respondents' Work

Based on the table and graph above, it can be seen that most respondents are from students as many as 42 respondents (42\%). Then privatesector workers that are as many as 18 people (18\%), followed by respondents with entrepreneurial work as many as 16 people or $16 \%$, then respondents with civil servant work are 15 people (15\%) and the fewest are respondents with other jobs as many as nine people (9\%).

\subsection{Level of education}

Respondents based on education level can be classified into six groups, which are an elementary school, junior high school, senior high school bachelor, master, and doctoral degree. Unfortunately, there are no respondents from elementary and junior high schools in this study. The results of which can be seen in the following tables and graphs. 
Table 4. Education Level of Respondents

\begin{tabular}{llrrrr}
\hline & \multicolumn{2}{c}{ Frequency } & Percent & Valid Percent & Cumulative Percent \\
\cline { 3 - 6 } & High school & 76 & 76.0 & 76.0 & 76.0 \\
\multirow{4}{*}{ Valid } & 13 & 13.0 & 13.0 & 89.0 \\
& Bachelor & 9 & 9.0 & 9.0 & 98.0 \\
& Master & 2 & 2.0 & 2.0 & 100.0 \\
& Doctoral & 100 & 100.0 & 100.0 & \\
\hline
\end{tabular}

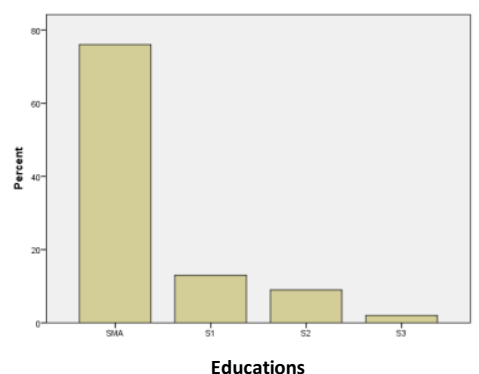

Fig 4. Graphic Level of Respondent Education

Based on the table and graph above, it shows that based on the education level, most respondents are students from the high school level, which are 76 respondents (76\%). For the bachelor level there are 13 people (13\%). They were followed by respondents from a master's degree as many as nine people (9\%). The fewest are respondents from the doctoral degree as many as two people (2\%).

Based on the results of the research, people in Surabaya were delighted with the construction of the BTS tower infrastructure. The results of the study show that the satisfaction aspect where most of the community's assessment of the condition and availability of network facilities available in the site area is very good and useful. The results of interviews with some of the residents, they have similar thought that the satisfaction of site towers in the city of Surabaya was excellent. Followed by the reasons given were the site condition was maintained and not dangerous, complete network facilities with good conditions, lighting around the site also useful to increase lighting in the vicinity of roads and residential areas.

In the aspect of cleanliness around the site tower due to the installation activities, network upgrades, and the addition of devices is perfect. It is indicated in the results of a questionnaire which most people assess the condition, availability of facilities, the network of various devices available in the site area, and also cleanliness around the tower. The results of interviews with the residents also mostly said that the condition of the area around the tower is immaculate because the condition of the water channel is good, so it does not cause a lot of standing water when it rains. It was reinforced by the results of the questionnaire, which showed the cleanliness of the site, and the addition of street lighting in the city of Surabaya was in the category of very comfortable for the people of Surabaya.

For security aspects, the residents evaluate that the condition of the safety of the environment around the tower site area is safe. The results of the questionnaire indicate that the level of security of network device facilities in the site area is very safe or good. Interviews with residents also found that they felt safe in the area around the site. It was shown from several years the construction of towers around the homes of residents did not cause unrest in the residents, as reported, like damage to the television and radio cause of lightning and radiation around the tower. So the results of the questionnaire on the security aspect are included in the category of very comfortable for the people. In the aspect of access from the residents' evaluation, it also has shown a good result. The residents feel that the workers do not experience any obstacles in the activity towards the location of the site. Access to the site location is straightforward and does not disturb the residents. The results of the interview showed that access at the site is very good for the residents around the tower site in Rungkut Surabaya. The reason given was because of the strategic location, the activity was also easy to do because it was well organized, and the vehicle parking was very easy. The results of the questionnaire also showed that the site tower access aspect was in a very comfortable categ ory for the people of Surabaya.

From the residents' assessment of all aspects of the satisfaction about the construction of BTS tower infrastructure, it can be concluded that the comfort level of the resident is in the comfortable category with a percentage value of $86.72 \%$. It is also inseparable from the participation of the resident and related agencies in the development of infrastructure in the presence of BTS towers, which was initially rejected because several factors residents were concerned about the impact of the BTS tower. And now, the people of Surabaya also play an active role in maintaining site cleanliness and security.

\section{Conclusion}

Based on the results of the research and discussion, the following conclusions can be drawn.

1. The people of Surabaya are delighted with the construction of the BTS tower infrastructure. The results of the questionnaire showed the Satisfaction aspect where most of the community's assessment of the condition and availability of network equipment facilities available in the site area was very good and fast.

2. In the aspect of safety and public concern for health due to the construction of BTS tower infrastructure, community assessments argue that safety and health conditions in the environment have no impact on the area around the site and are safe for the community.

3. In the aspect of access to community evaluation, it is also excellent. The community feels it is easy for workers to carry out activities to access the site. Convenience is also found in conducting operations on site. 


\section{References}

[1] D. Satria, A. Alanda, A. Erianda, and D. Prayama, "Network Security Assessment Using Internal Network Penetration Testing Methodology," JOIV Int. J. Informatics Vis., 2018, doi: 10.30630/joiv.2.4-2.190.

[2] D. Abdullah, "PERANCANGAN SISTEM INFORMASI PELAYANAN KAPAL DI PT. PELABUHAN INDONESIA (PERSERO) CABANG LHOKSEUMAWE," JITTER, 2015.

[3] R. R. Sampaio, H. B. De Barros Pereira, and C. P. Rosa, "Mapping information and knowledge flow: IT governance from the perspective of social networks," Gest. e Prod., 2012, doi: 10.1590/S0104-530X2012000200011.

[4] A. G. Palilu, "Studi Awal Perencanaan Jumlah Kebutuhan BTS dalam Penerapan Menara Bersama Telekomunikasi di Kota Palangka Raya," Bul. Pos dan Telekomun., 2015, doi: 10.17933/bpostel.2014.120403.

[5] N. Zendrato and M. Zarlis, "Analysis of Mamdani Method to Increase the Level of the Advantages of Infrastructure Development for Optimal Network," in IOP Conference Series: Materials Science and Engineering, 2020, doi: 10.1088/1757-899X/769/1/012053.

[6] M. S. Kumar and P. J, “Analysis of Network Function Virtualization and Software Defined Virtualization,” JOIV Int. J. Informatics Vis., 2018, doi: 10.30630/joiv.1.4.40.

[7] A. Yurekli et al., "GSM base station electromagnetic radiation and oxidative stress in rats," Electromagn. Biol. Med., 2006, doi: $10.1080 / 15368370600875042$.

[8] S. Maruyama, K. Tanahashi, and T. Higuchi, "Base Transceiver station for W-CDMA system," Fujitsu Sci. Tech. J., 2002.

[9] J. Suyono et al., "Medium Enterprises, Campus Infrastructure Development with Private Partnership," Int. J. Eng. Technol., 2018, doi: 10.14419/ijet.v7i3.6.17486. 